\title{
Chirurgijns op de schepen van de Verenigde Oost-Indische Compagnie
}

\begin{abstract}
'In ons Vaderland, daar de Heelkunde op den veragtelijksten voet is, en eeniglijk in onze voornaame steden door eenige bekwame handartzen voor een volstrekt verval bewaard wordt, beginnen onze ScheepsDoctoren hun onderwijs met baardscheren, daarna komt'er Pleisters smeeren en Aderlaaten bij; de Patroon stopt zijnen leerling vervolgens een kort Begrip van Ontleed en Heelkunde in de Hand; een gelukkig geheugen en eenige geradbraakte Latijnsche Kunstwoorden volmaakten de zaak. Een jammerlijk Examen volgt, eenige Guldens worden betaald, en zie daar mijn Aesculaap voorzien van een zeebrief waarbij hem geoorloofd wordt de zeebouwende Onderdaanen van den Staat door alle de vier Werelddelen te medicamenteeren tot 'er geneezing of de Dood na volgt.'
\end{abstract}

Dit schrijft de achttiende-eeuwse arts Jacob Voegen van Engelen over de scheepschirurgijns die toen dienden op de schepen van bijvoorbeeld de Verenigde Oost-Indische Compagnie (VOC) of bij de marine. De scheepschirurgijns uit het tijdperk van de zeilvaart hadden een volstrekt negatief imago - zij hebben het nog. Maar klopt dat beeld wel? Waren de scheepschirurgijns van de zeventiende en achttiende eeuw wel zo slecht opgeleid en onbekwaam?

De medische wereld van de zeventiende en achttiende eeuw was van mening dat de lichaamssappen ('humoren') bij een gezond mens in evenwicht waren. Wanneer iemand ziek werd, was dat evenwicht verstoord en moest het worden hersteld. Dat deed men door purgeren, aderlaten, klisteren, door verbanden aan te leggen en dranken voor te schrijven. Dit was het vakgebied van de chirurgijn. Hij kreeg zijn opleiding in een chirurgijnsgilde. Uit onderzoek blijkt dat de opleiding van chirurgijnsleerling tot meesterchirurgijn in de achttiende eeuw meestal een jaar of tien duurde. De leerling schreef zich rond zijn veertiende in bij het gilde, kreeg een plaats bij een meesterchirurgijn bij wie hij het vak ging leren, behaalde binnen een jaar of zes zijn knecht-examen en studeerde rond zijn 25ste af met het afleggen van de meesterproef die gewoonlijk bestond uit het slijpen van lancetten, het aderlaten, het trepaneren van een schedel en uit een theoretisch examen over de anatomie van botten en aderen, chirurgie en de materia chirurgica. De heelkunde was het terrein van de chirurgijn, in tegenstelling tot dat van de geneeskunde dat werd beoefend door de universitair geschoolde arts. Was deze heelkundige opleiding voldoende voor het werk aan boord van de schepen van de Verenigde Oost-Indische Compagnie?

De VOC was de belangrijkste maritieme handelsorganisatie van de Republiek der Verenigde Nederlanden. Zij was opgericht in 1602 en ging ten onder in 1799. De Compagnie bezat het handelsmonopolie voor de producten uit Azië, zoals peper, nootmuskaat, Indiaas katoen, Chinese thee en Japanse zijde. Om dit handelsmonopolie af te dwingen had de VOC het recht er een leger op na te houden, oorlog te voeren, gebieden te veroveren en verdragen te 
sluiten met locale heersers. Zij was, kortom, een verlengstuk van de staat. Gedurende de twee eeuwen van haar bestaan heeft de VOC voortdurend oorlog gevoerd, zowel te land als ter zee. Zo veroverde zij een enorm handelsgebied, dat zich uitstrekte van Kaap de Goede Hoop tot en met Japan.

Om de schepen te bemannen, de legers van soldaten te voorzien, handel te drijven en de Aziatische bezittingen te besturen, had de Compagnie manschappen nodig. En niet zo weinig ook. Alleen al aan scheepsbemanningen had de VOC jaarlijks ongeveer 25.000 man nodig; dan hebben we het nog niet eens over de grote aantallen soldaten. De schepen die ieder jaar naar Azië voeren, werden volgestouwd met zo veel mogelijk zeelieden en militairen. Een uitvarend schip telde gemiddeld 200 tot 300 opvarenden, waaronder ongeveer honderd soldaten. Tussen 1602 en 1795 zijn op de schepen van de VOC ongeveer één miljoen mensen vertrokken uit de Republiek. En op elk van de schepen waren chirurgijns te vinden.

Hun aanwezigheid was op zich al bijzonder; een scheepsdokter aan boord van schepen die de wereldzeeën bevoeren was tot dan toe geen automatisme geweest. In het tijdperk van vóór de VOC (en vóór de twee jaar eerder opgerichte Engelse OostIndische Compagnie) waren het vooral de Spaanse en Portugese galjoenen die de oceanen hadden bevaren. Scheepsdoktoren aan boord waren toen zeldzaam. Er ging wel eens een arts mee, maar dan als persoonlijke lijfsheer van een hooggeplaatste zeeofficier, en niet voor de gezondheid van de bemanning. Het werd op de Spaans/ Portugese galjoenen vooral belangrijk geacht dat de menselijke ziel zijn reis naar de Hemel (dan wel de Hel) goed voorbereid aanvaardde. Zodoende waren er wel altijd priesters aan boord.

Toen de Nederlanders (en de Engelsen) het Portugese imperium overnamen, richt- ten zij zich meteen op het lijfsbehoud van de opvarenden van de schepen die in de onbekende landen met onbekende ziekten kennis maakten. Op elke Oost-Indiëvaarder plaatste de VOC drie scheepschirurgijns: een opperchirurgijn, een onderchirurgijn en een derde meester. Tijdens de twee eeuwen van het bestaan van de Compagnie zijn op deze wijze ongeveer 10.000 chirurgijns naar Azië vertrokken.

Deze scheepschirurgijns waren geen overbodige luxe. Het spreekt vanzelf dat tijdens een zeereis van minimaal acht maanden met een scheepspopulatie van ongeveer 200 à 300 man ziekte regelmatig de kop opstak. Dat konden verkoudheden en griep zijn, maar ook serieuzere aandoeningen. Tegen de tijd dat men de evenaar naderde was de voorraad vers water en verse groenten al lang en breed uitgeput en behoorde scheurbuik tot de mogelijkheden; een bemanningslid wilde zich tijdens het uitzetten of binnenhalen van de zeilen nog wel eens bezeren: kneuzingen en botbreuken werden snel opgelopen. Dit behoorde allemaal nog wel tot het competentieterrein van de chirurgijn. Maar er deden zich ook lastigere en meer exotische ziekten voor zoals beri-beri, dysenterie, oogontstekingen, malaria, waterpokken, mazelen, tyfeuse koortsen (vlektyfus), mijnworm, lintworm, tryponosomiasis, framboesia, syfilis, lepra en elephantiasis om er maar een paar te noemen. Wat kon een scheepschirurgijn daar tegen doen? De chirurgijn stond tegenover zulke ziekten machteloos; dat verklaart in de eerste plaats zijn negatieve imago.

Uiteraard waren bacteriën, virussen en vitaminen nog niet bekend; de ontdekking daarvan liet op zich wachten tot de negentiende eeuw. Toch deden de scheepschirurgijns wat zij konden met de beperkte middelen waarover zij beschikten en naar de maatstaven van die tijd. Zij zorgden voor een kleine reserve van apart voedsel 
aan boord ten behoeve van de patiënten, zoals bijvoorbeeld sinaasappels. Wanneer de voorraad hiervan was uitgeput, gaven zij de scheurbuikpatiënt een azijndrankje omdat zij dachten dat de zure en helende smaak van sinaasappels ook in azijn te vinden was. Bij epidemieën probeerde de scheepschirurgijn het tussendek schoon te krijgen door buskruit te branden en liet hij het dek schrobben met een mengsel van water en azijn. Een enkele chirurgijn kwam zelfs op de gedachte om de inhoud van alle scheepskisten en de kleren van de opvarenden te laten luchten op het bovendek wat inderdaad een effectief middel was tegen de verspreiding van vlektyfus (veroorzaakt door de kleerluis). Verder reikten zij braakmiddeltjes uit, tapten bloed af en gaven een extra glaasje wijn aan de patiënt.

De scheepschirurgijn zelf stond, veel meer dan de andere officieren aan boord, bloot aan het grote gevaar van zijn beroep: besmetting. Het risico daarop was niet onaanzienlijk. In de tweede helft van de achttiende eeuw was zijn kans op overlijden ten gevolge van ziekte binnen vijf jaar na uitvaren groot. Toch bleven de scheepschirurgijns zich melden in de havens van de Republiek waar de VOC een kantoor had. Men vraagt zich af waarom? Wat maakte een baan als scheepschirurgijn bij de VOC zo de moeite waard? Zij kwamen zelfs uit Duitsland omdat de Republiek niet meer aan de vraag naar chirurgijns kon voldoen. Dat gold ook voor zeelieden en soldaten van wie eveneens vele duizenden uit Duitsland afkomstig waren. Verschillende factoren speelden een rol bij de beslissing om als scheepschirurgijn bij de VOC te gaan werken. Het was het VOC personeel toegestaan een beperkte hoeveelheid handelswaren mee te nemen uit de Oost waarmee men voor eigen rekening kon handelen. Bijna elke opvarende deed hieraan mee, zo ook de scheepschirurgijn. Het was een middel om bij te verdienen en het salaris aan te vullen. Maar er waren voor de scheepschirurgijn meer redenen dan geldelijk gewin om dienst te nemen bij de VOC. Voor een aspirant meesterchirurgijn was de VOC-experience een belangrijke stap in zijn beroepsontwikkeling. Aan boord en overzee kreeg de scheepschirurgijn veel meer te zien dan wat een meesterchirurgijn in zijn chirurgijnswinkel in Nederland of Duitsland gedurende zijn leven aan ziekten te behandelen kreeg. Bovendien werkte hij aan boord van de schepen en in de handelsposten in Azië niet alleen als chirurgijn maar ook als arts, iets wat verboden was in de Republiek aangezien de chirurgijn niet universitair geschoold was. Kortom, het avontuur bij de VOC verbreedde de horizon, niet alleen letterlijk maar ook beroepsmatig.

\section{Iris Bruijn}

\section{De auteur:}

Mw. dr. I.D.R. Bruijn is historica en werkzaam als compliance officer bij een internationaal advocatenkantoor te Amsterdam en deze bijdrage is gebaseerd op haar boek 'Ship's Surgeons of the Dutch East India Company Commerce and the Progress of Medicine in the Eighteenth Century' (Amsterdam: Leiden University Press; 2009). ISBN 9789087280512. 